\title{
In-Vitro and In-Vivo Assessment of Anti-Asthmatic Activity of Polyherbal Ayurvedic Drug
}

\author{
${ }^{1}$ Kajaria Divya*, Kajaria Ankit ${ }^{2}$, Tripathi. J.S ${ }^{1},{ }^{1}$ tiwari. S.K. ${ }^{1}$ \\ ${ }^{I}$ Dept. of Kayachikitsa,Faculty of Ayurveda,Institute of Medical Sciences, B.H.U. - 221005, Varanasi, India. \\ ${ }^{2}$ Dept. of Biomedical Sciences, Indian Institute of Technology, B.H.U.-22005, Varanasi, India.
}

\begin{abstract}
About $80 \%$ of asthmatic turn to alternative or complementary therapies typically in conjunction with their regular allopathic medication. The role of complementary and alternative medicine in adult asthma treatment is limited because these approaches have been insufficiently researched and their effectiveness is largely unproven. In the present study in -vivo and in-vitro effectiveness of a polyherbal Ayurvedic drug is evaluated for its anti-asthmatic activity. For in -vitro assessment of anti-asthmatic property of drug antiinflammatory, analgesic, immunomodulator effect, and antihistaminic, anti-cholinergic, mast cell stabilizing activity, anti-anaphylactic activity and bronchodilator effect were screen on animal models. Evaluation of Effect of Drug Distribution on Lung Mechanics is also evaluated using MATLAB. In a randomised,open, placebo controlled trial the effects of drug was compared with placebo medication (normal saline) in 60 adults with mild to moderate asthma as an adjunct to conventional treatment. Animal studies showed that drug possess significant mast cell stabilizing activity, immunomodulator activity, bronchodilator activity and antianaphylactic activity. Insignificant anti-cholinergic activity was found in the drug. There was significant improvement found in pulmonary function test (including FEVI, FVC and PEFR)in the group treated with polyherbal drug. Improvement remain constant in consecutive follow-ups signifies that there is no reverse bronchoconstriction after discontinuation of drug. This study signifies that polyherbal drug (Shirishadi) may prove beneficial future alternative remedy for asthma and its effect is similar to that of modern contemporary drug when given through nasal route.
\end{abstract}

Key Words: Shirishadi polyherbal compound, immunomodulation, MATLAB, PFT.

\section{Introduction}

Now progress in western medical research has reached a bottleneck, as single compound drugs are costly to create, synthesis and manufacture. To see real and sustained progress in research it is necessary to utilize traditional remedies to develop advanced medicines. During the past decade there has been a paradigm shift from utilizing single target drugs to multi-target drugs. The concept of multi-targeted therapy represents the conventional herbal medicine treatments that often employ multicomponent plant tissues extract as natural product mixtures. However very few phytomedicinal products have clear or systematic documentation comparable to that of chemically synthesized drugs as single chemical compound. In present study we aim to justify the use of self experienced polyherbal drug in the management of asthma and explore its pharmacodynamic properties. Shirishadi is a polyherbal drug having equal quantity of three herbs namely Shirisha (Albizia lebbeck), Nagarmotha (Cyprus rotandus) and Kantakari (Solanum xanthocarpum). All the three herbs were collected from the local market of Varanasi (U.P, India) and then identified by Prof.A.K.Singh ( Dravyaguna deptt of Ayurveda, IMS,BHU). Hydroethanolic extract of the three herbs were extracted out by hot percolation using soxhlet apparatus. Shirishadi polyherbal compound is a self experienced Ayurvedic drug use for the management of allergic respiratory diseases. In Ayurveda Shirisha (Albizia lebbeck) is told to be Vishaghana i.e. destroying the toxins present in the body. It is mainly indicated in allergic conditions such allergic rhinitis, allergic asthma, urticaria etc ${ }^{1}$. Solanum xanthocarpum known as Kantakari in Ayurveda and is very effective in respiratory tract disorders ${ }^{2}$. It is found to have strong bronchodilator effect along with antiinflammatory property ${ }^{3}$. Cyprus rotundus or Mustaka is thought to have originated in India and then spread from there during the past 2,000 years. Its uses in modern Ayurvedic medicine are primarily for treating fevers and digestive system disorders (diarrhea, vomiting, indigestion, etc.).

\section{Material And Methods}

Aminopyrine - 50mg/Kg, oral administration, Carrageenin, Pentazocin- $10 \mathrm{mg} / \mathrm{Kg}$ bwt, I.P. administration, 1hour before aceti acid injection, Endomethacin- $25 \mathrm{mg} / \mathrm{Kg}$ bwt, oral administration, 1hour before carrageenin injection, Acetic acid- $0.7 \%$ acetic acid at a dose of $0.1 \mathrm{ml} / 10 \mathrm{~g}$ given Intraperitonealy, Cyclophosphamide (Sigma, life science)- The Cyclophosphamide was suspended in 0.5\% Carboxy methyl cellulose solution in distilled water. The solution was administered intraperitoneally at a dose of $30 \mathrm{mg} / \mathrm{kg} \mathrm{b} / \mathrm{w}$, Ova albumin - Intraperitoneal injection of $0.5 \mathrm{ml}$ and $10 \% \mathrm{w} / \mathrm{v}$ solution, Atropin sulphate (E.Merck,Germany), 
Anesthetic ether (BDH, India), Dexchlorpheniramine maleate (Schering) dissolved in distilled water to make desired concentration, Histamine dihydrochloride (Sigma Chemical Co. U.S.A.) dissolved in distilled water to make desired concentration, Mepyramine melate- $(10 \mathrm{mg} / \mathrm{kg}=0.1 \%$ Soln.), Acetylcholine chloride (Sigma Chemical Co. U.S.A.), Ketotifen $-1 \mathrm{mg} / \mathrm{kg}$, oral administration.

Analgesic and Anti-inflammatory Activity (Winter et al. 1962)

For the present experiment, carrageenin suspension was prepared as a homogenous suspension of powder in $0.9 \%$ sodium chloride solution (sterile normal saline) with the help of mortar \& pestel. A volume of $0.1 \mathrm{ml}$ of suspension was injected through a 26 gauge needle into the plantar surface of the right hind paw below the plantar aponeurosis $1 \mathrm{~h}$ after the oral administration of test materials. The volume of hind paw of the rats upto the ankle joint was measured plethysmographically, by the mercury displacement method. The volume was measured $1 \mathrm{~h}, 2 \mathrm{~h}, 3 \mathrm{~h}, 4 \mathrm{~h} \& 24$ after the administration of drug. The extract was administered at 50, 200 and 500 $\mathrm{mg} / \mathrm{kg}$ body weight. Endomethacin $25 \mathrm{mg} / \mathrm{kg}$ body weight was used as standard antiinflammatory agent.

Table No. 1 : Anti-inflammatory activity of crude extract of Shirishadi compound by carrageenin induced rat paw edema

\begin{tabular}{|l|l|l|l|l|l|}
\hline \multirow{2}{*}{ Groups } & \multicolumn{5}{|l|}{ \% Increase in Paw Volumes (ml × 1000) \pm SEM (percent inhibition) } \\
\cline { 2 - 6 } & $1 \mathrm{~h}$ & $\mathrm{~h}$ & $3 \mathrm{~h}$ & $4 \mathrm{~h}$ & $24 \mathrm{~h}$ \\
\hline Control & $1.78 \pm 0.77$ & $3.0 \pm 0.15$ & $3.61 \pm 0.20$ & $4.0 \pm 1.2$ & $1.93 \pm 0.11$ \\
\hline Standard (Indomethacin & $0.72 \pm 3.7$ & $0.69 \pm 0.60$ & $0.67 \pm 0.66$ & $0.65 \pm 0.37$ & $0.66 \pm 0.52$ \\
25mg/kg) & $59 \%$ & $77 \%$ & $81 \%$ & $92 \%$ & $66 \%$ \\
& & & & \\
\hline Shirishadi 50mg/ & $1.06 \pm 0.68$ & $0.99 \pm 0.66$ & $0.93 \pm 0.33$ & $0.89 \pm 0.33$ & $0.78 \pm 0.41$ \\
100gm bwt & $40 \%$ & $67 \%$ & $74 \%$ & $77 \%$ & $59 \%$ \\
\hline Shirishadi 200mg/100gm & $1.0 \pm 1.0$ & $0.97 \pm 0.14$ & $0.92 \pm 0.24$ & $0.88 \pm 0.57$ & $0.77 \pm 0.24$ \\
bwt & $43 \%$ & $67.66 \%$ & $74.28 \%$ & $79 \%$ & $60 \%$ \\
\hline Shirishadi 500mg/100gm & $0.95 \pm 0.33$ & $0.95 \pm 0.37$ & $0.83 \pm 0.66$ & $0.76 \pm 0.63$ & $0.66 \pm 0.33$ \\
bwt & $46.6 \%$ & $68 \%$ & $77 \%$ & $81 \%$ & $65 \%$ \\
\hline
\end{tabular}

Values are mean \pm SEM $(\mathrm{N}=3)$.

\section{Acetic acid induced writhing test}

Pentazocin and aspirin were used as standard analgesic agents. Intraperitoneal injection of acetic acid $(0.7 \%)$ at a dose of $0.1 \mathrm{ml} / 10 \mathrm{~g}$ of body weight was used to create pain sensation. The number of writhings was calculated for $10 \mathrm{~min}, 10 \mathrm{~min}$ after the application of acetic acid.

Table No 2: Effect of Shirishadi Extract on acetic acid induced writhing response in rodents: (Saha et al., 2007)

\begin{tabular}{|c|c|c|c|}
\hline Groups & Dose of Drug & Writhing $^{\mathrm{b}}$ & $\%$ Inhibition \\
\hline Control & -- & $15.6 \pm 0.50$ & -- \\
\hline \multirow[t]{2}{*}{ Standard } & $\begin{array}{l}\text { Pentazocin } 10 \mathrm{mg} / \mathrm{Kg} \text {, } \\
\text { i.p. }\end{array}$ & $4.3 \pm 0.66 * *$ & $71.2 \%$ \\
\hline & Aspirin $25 \mathrm{mg} / \mathrm{Kg}$, i.p. & $8.0 \pm 1.15 * *$ & $63.5 \%$ \\
\hline \multirow[b]{2}{*}{ Shirishadi } & 200mg/100gm bwt, p.o. & $7.66 \pm 0.88 * *$ & $65.6 \%$ \\
\hline & $\begin{array}{l}500 \mathrm{mg} / 100 \mathrm{gm} \text { bwt, } \\
\text { p.o. }\end{array}$ & $6.33 \pm 0.88 * *$ & $70.9 \%$ \\
\hline \multirow{3}{*}{$\begin{array}{l}\text { One way } \\
\text { ANOVA }\end{array}$} & $\mathrm{F}$ & 46.94 & -- \\
\hline & $\mathrm{df}$ & 4,12 & -- \\
\hline & $P$ & $<0.001$ & -- \\
\hline
\end{tabular}

a $1 \mathrm{hr}$ after treatment, mice were injected i.p. with $0.7 \%(\mathrm{v} / \mathrm{v})$ acetic acid $(0.1 \mathrm{ml} / 10 \mathrm{~g}) ; 10$ minutes after the injection, the number writhing was counted for $10 \mathrm{~min}$.

b Values are mean \pm SEM $(\mathrm{n}=5$, for control \& 3in drug treated groups $)$; One-way ANOVA; $* * P<0.001$, compared to control.

\section{Radiant heat tail-flick method}

The central analgesic activity of the plant material was studied by measuring drug-induced changes in the sensitivity of the pre-screened (reaction time: $2-4 \mathrm{sec}$ ) mice to heat stress applied to their tails by using a Medicraft Analgesiometer Mask-N (D'Amour and Smith,1941) and described previously (Saha et al., 2007).Briefly, the current intensity passing through the naked nicrome wire was maintained at 5 ampere. The distance between the heat source and the tail skin was $1.5 \mathrm{~cm}$ and cut-off reaction time was fixed at 10 second to avoid any tissue damage. Pentazocin was used to compare the analgesic effect of the plant extract. 
Table No 3: Effects of crude extract ${ }^{a}$ on radiant heat tail-flick response in rodents: (D'Amour and Smith, 1941)

\begin{tabular}{|c|c|c|c|c|}
\hline \multirow[b]{2}{*}{ Groups } & \multirow[b]{2}{*}{ Dose of Drug } & \multicolumn{3}{|c|}{ Reaction Time (sec) } \\
\hline & & $\begin{array}{l}30 \text { (mins) } \\
(\% \text { elongation })\end{array}$ & $\begin{array}{l}0 \text { (mins) } \\
(\% \text { elongation })\end{array}$ & $\begin{array}{l}120 \text { (mins) } \\
(\% \text { elongation })\end{array}$ \\
\hline Control & -- & $4.65 \pm 0.15$ & $4.82 \pm 0.16$ & $4.98 \pm 0.20$ \\
\hline Standard & $\begin{array}{ll}\text { Pentazocin } & 10 \mathrm{mg} / \\
\text { kg bwt, i.p. } & \\
\end{array}$ & $8.65 \pm 0.71 * *$ & $6.45 \pm 0.45^{* *}$ & $5.89 \pm 0.37 * *$ \\
\hline \multirow[t]{2}{*}{$\begin{array}{l}\text { Shirishadi } \\
\text { Compound }\end{array}$} & $\begin{array}{l}200 \mathrm{mg} / 100 \mathrm{gm} \\
\text { bwt, p.o. }\end{array}$ & $\begin{array}{l}7.41 \pm 1.17 * * \\
(58.1 \%)\end{array}$ & $\begin{array}{l}7.10 \pm 0.30 * * \\
(56.3 \%)\end{array}$ & $\begin{array}{l}6.08 \pm 0.21 * * \\
(49 \%)\end{array}$ \\
\hline & $\begin{array}{l}500 \mathrm{mg} / 100 \mathrm{gm} \\
\text { bwt, p.o. }\end{array}$ & $\begin{array}{l}7.98 \pm 0.12^{* *} \\
(61.1 \%) \\
\end{array}$ & $\begin{array}{l}7.57 \pm 0.45 * * \\
(59 \%)\end{array}$ & $\begin{array}{l}6.75 \pm 0.15^{* *} \\
(54 \%)\end{array}$ \\
\hline \multirow{3}{*}{$\begin{array}{ll}\text { One } & \text { way } \\
\text { ANOVA } & \end{array}$} & $\mathrm{F}$ & 68.5 & 27 & 5.34 \\
\hline & $P$ & $<0.001$ & $<0.001$ & $<0.001$ \\
\hline & $\mathrm{df}$ & 7,40 & 7,40 & 7,40 \\
\hline
\end{tabular}

a .per oral administration of vehicle and crude extract, radiant heat intensity was $5 \mathrm{amp}$.

b morphine was administered sub-cutaneously.

c Values are mean \pm SEM $(\mathrm{n}=5$ ); One-way ANOVA; $\mathrm{df}=7,40 ; * * P<0.01, * P<0.05$ compared to control.

\section{Immunomodulator Activity (S.Govindan ,2004 \& R.E.Fleming,1997)}

The animals were divided into the 3 groups containing 6 animals (mice) in each group. Group1 (Control group) received Carboxy Methyl Cellulose (CMC) for 14 days and group 2 (Challenge group) received CMC for 10days, on 11th, 12th and 13th day Cyclophosphamide intraperitonially at a dose of $30 \mathrm{mg} / \mathrm{kg} \mathrm{b} / \mathrm{w}$. Groups 3 (Test group) received ethanolic extract of the drug at a dose of 500mg/kg body weight orally for 14 days. On days 11,12 and 13th day Cyclophosphamide solution was given intraperitonially at a dose of $30 \mathrm{mg} / \mathrm{kg}$ $\mathrm{b} / \mathrm{w}$ one hr after the administration of the extract.

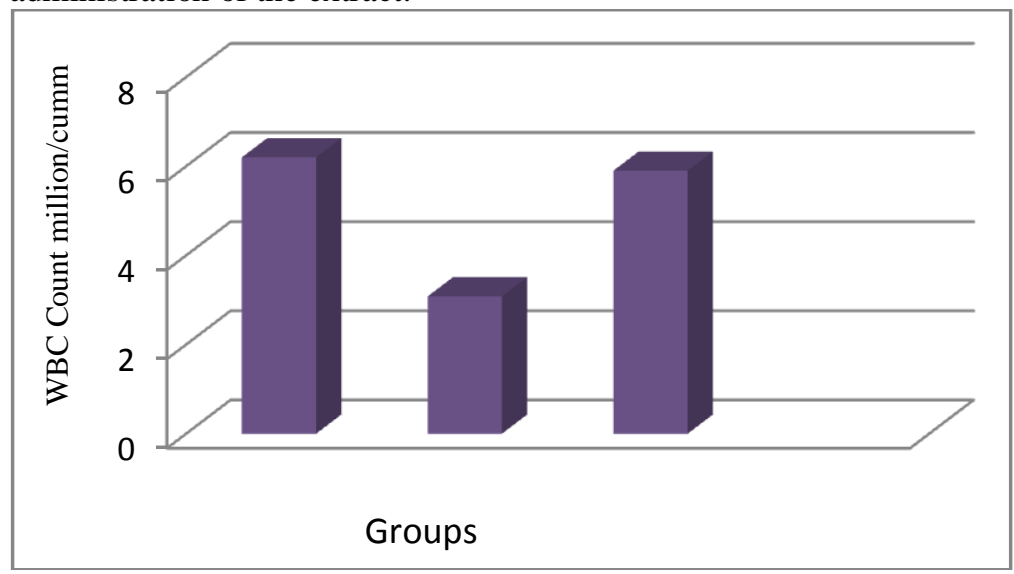

All values are mean \pm SEM, $\mathrm{n}=6$.

$* * * \mathrm{P}<0.001$ when compared with control group and, \#\#\#P<0.001, when compared with Cyclophosphamide treated group (Students t test).

b. $\mathrm{P}<0.01$, when compared with Cyclophosphamide treated group (One way ANOVA).

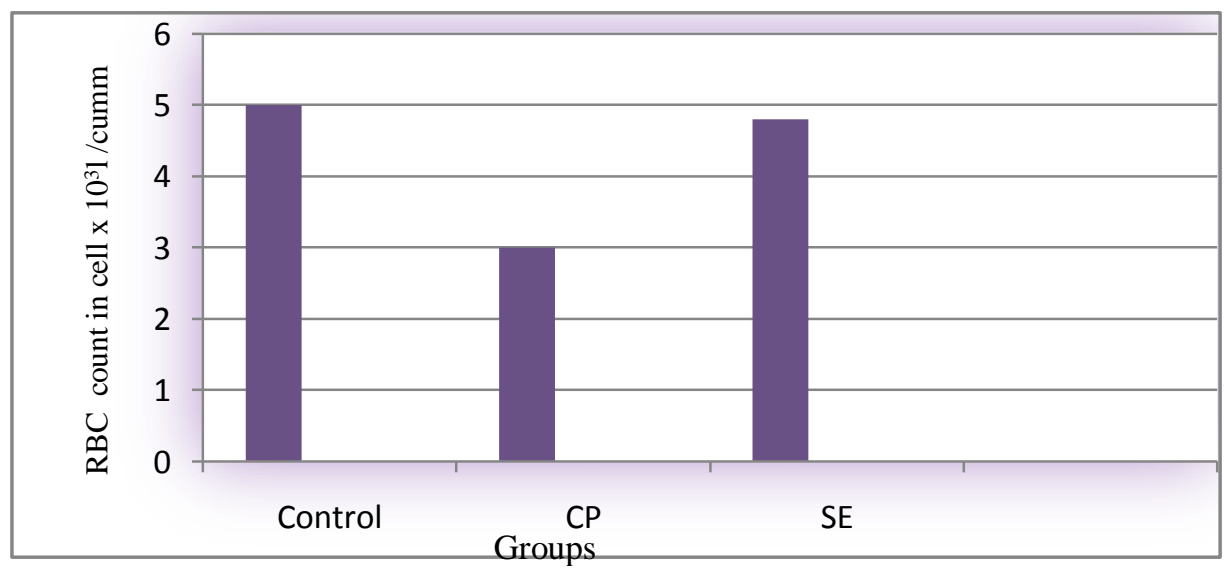

Figure 2. Effect of ethanolic extract of Shirishadi Compound on RBC count. All values are mean \pm SEM, $n=6$. 
$* * * \mathrm{P}<0.001$ when compared with control group and, \#\#\#P<0.001, when compared with Cyclophosphamide treated group (Students t test).

b. $\mathrm{P}<0.01$, when compared with Cyclophosphamide treated group (One way ANOVA).

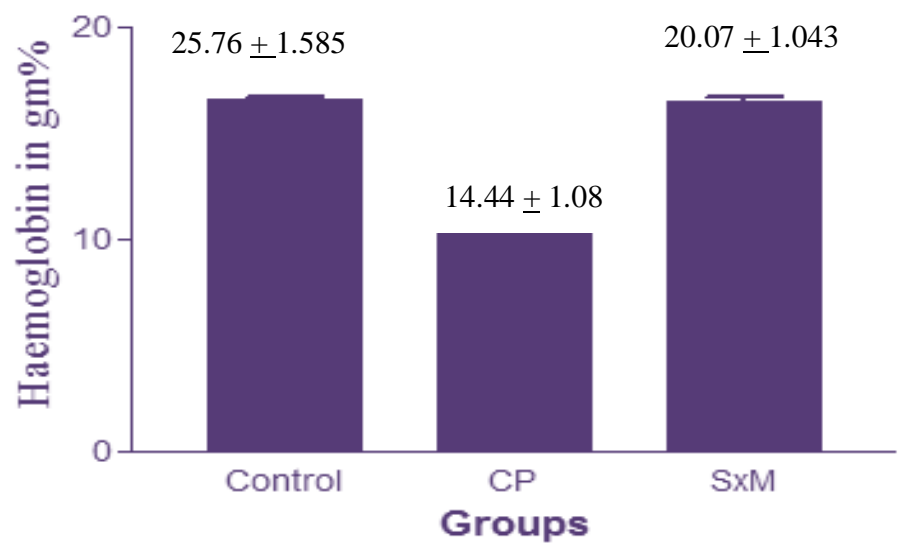

Figure 3. Effect of ethanolic extract of Shirishadi Compound on Haemoglobin estimation.

All values are mean \pm SEM, $n=6$.

$* * * \mathrm{P}<0.001$ when compared with control group and, $\mathrm{P}<0.001$, when compared with Cyclophosphamide treated group (Students t test).

b. $\mathrm{P}<0.01$, when compared with Cyclophosphamide treated group (One way ANOVA).

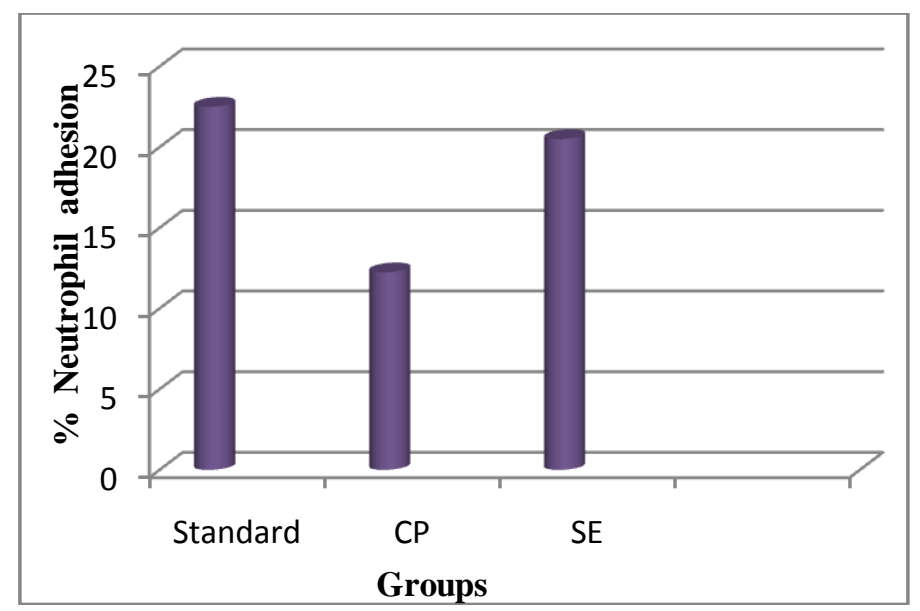

Figure 4. Effect of ethanol extract of Shirishadi Compound on neutrophil adhesion test on

Cyclophosphamide treated rats.

All values are mean \pm SEM, $n=6$.

$* * \mathrm{P}<0.01$ when compared with control group, $\mathrm{P}<0.001$ when compared with Cyclophosphamide treated group.(Students t' test).

b. $\mathrm{P}<0.01$ when compared with Cyclophosphamide treated group ( one way Anova).

\section{Egg albumin induced anaphylaxis in guinea pigs}

Guinea pigs were sensitized by two intraperitoneal injections of $0.5 \mathrm{ml}$ and $10 \% \mathrm{w} / \mathrm{v}$ solution of egg albumin at a 48-h interval. After sensitization, the animals were divided into two groups. Animals of group I received $0.5 \% \mathrm{CMC}$ and served as control group. Animals of Group II received ethanolic extract of Shirishadi compound $(500 \mathrm{mg} / \mathrm{kg}$, p.o, once daily) dissolved in distilled water for 14 days. On day 14, two hours after treatment, the animals were challenged with $0.5 \mathrm{ml}$ of $2 \% \mathrm{w} / \mathrm{v}$ solution of egg albumin into the saphenous vein. Guinea pigs were observed for the onset of symptoms such as dyspnoea and cyanosis, duration of persistence of symptoms (min.) and mortality. 
Table No 4 : Effect of Shirishadi Compound on egg albumin induced anaphylaxis in rats.( Gupta et al)

\begin{tabular}{|l|l|l|l|l|}
\hline \multirow{2}{*}{ Group } & \multicolumn{2}{|l|}{ Pre convulsion time (min) } & $\begin{array}{l}\text { Percent } \\
\text { protection } \\
\text { Mortality (\%) }\end{array}$ \\
\cline { 2 - 5 } & $\begin{array}{l}\text { Onset } \\
\text { (min) }\end{array}$ & $\begin{array}{l}\text { Duration } \\
\text { (min) }\end{array}$ & $\begin{array}{l}\text { Severity } \\
\text { (score) }\end{array}$ & $70 \%$ \\
\hline $\begin{array}{l}\text { Group I } \\
\text { (Control) }\end{array}$ & $1.246 \pm 0.056$ & $23.66 \pm 0.345$ & $9.4 \pm 0.306$ & $0 \%$ \\
\hline $\begin{array}{l}\text { Group II } \\
\begin{array}{l}\text { Shirishadi compound } \\
\text { 500mg/ Kg, p.o. }\end{array}\end{array}$ & $2.914 \pm 0.088^{*}$ & $7.054 \pm 0.131^{*}$ & $3.0 \pm 0.615^{*}$ & \\
\hline
\end{tabular}

\section{Study on Isolated Frog Rectus Abdominis Muscle preparation}

A frog is pithed and laid out on frog dissection board. The skin of the anterior abdominal wall is cut by a midline incision which is extended laterally upto the anterior aspects of the limbs. This exposes the flat whitish muscles of the anterior abdominal wall from their pubic origin to their sternal insertion. The two recti are removed and placed in frog Ringer solution in a shallow dish. They are carefully cleaned and one of them is trimmed to the desired size and mounted in an organ bath of $5 \mathrm{ml}$ capacity, at room temperature, aerated with oxygen. For recording purposes, an isotonic lever with a sideways writing point is used tangential to the smoked drum, balanced for a tension of $2.5 \mathrm{gm}$ with an extra load of $1 \mathrm{gm}$ on the long arm. A standard solution of Ach is added to the bath and a slow contraction is recorded on the slow moving drum for exactly 90sec. The drum is stopped and the bath fluid is replaced by fresh Frog- Ringer. An extra $1 \mathrm{~g}$ load is used to extend the muscle to its original length.

Table No 5 : Competitive Drug Antagonism in Frog Rectus Muscle Preparation

\begin{tabular}{|c|c|c|c|c|c|}
\hline S.No. & $\begin{array}{l}\text { Dose of } \\
\text { Acetylcholine } \\
(10 \mu \mathrm{g} / \mathrm{ml})\end{array}$ & $\begin{array}{l}\text { Log molar } \\
\text { concentration of } \\
\text { Acetylcholine }\end{array}$ & $\begin{array}{ll}\text { Control } & \% \\
\text { maximum } & \\
\text { response } & \end{array}$ & $\begin{array}{lr}\text { Dose of } \\
\text { S.E. \& } \\
\text { B.E.(mg/ml) }\end{array}$ & $\begin{array}{l}\text { \% Inhibition } \\
\text { of maximum } \\
\text { Ach } \\
\text { contraction } \\
\text { by Shirishadi } \\
\text { compound }\end{array}$ \\
\hline 1. & $0.1 \mathrm{ml}$ & 7.05 & $30+2.03$ & 1 & $2.06+1.76$ \\
\hline 2. & $0.2 \mathrm{ml}$ & 6.66 & $56+1.45$ & 5 & $4.36+0.56$ \\
\hline 3. & $0.4 \mathrm{ml}$ & 6.35 & $75 \pm 3.05$ & 10 & $10 \pm 3.12$ \\
\hline 4. & $0.8 \mathrm{ml}$ & 6.20 & $89+1.25$ & 20 & $24 . \overline{98}+2.34$ \\
\hline 5. & $1.6 \mathrm{ml}$ & 5.75 & $99.9+0.98$ & 50 & $30.2+0.23$ \\
\hline
\end{tabular}

All the values are mean + SDE, where $n=3$.

\section{Study on Isolated Perfused Frog's Heart}

A frog was pithed and pinned on frog broad to expose heart. A thread was passed under the vena cava to tie the cannula and make a small nick in it. Then a small nick is made in one of the aorta. The frog board was fixed on the plane stand and venous cannula was tied to the inferior venacava and perfusion was started. The venous pressure was maintained at $2-4 \mathrm{~cm}$ of water by altering the height of perfusion bulb and then opening completely the screw clamp. A universal lever was then fixed on the plain stand. A small thin hook was passed through the tip of the ventricle and tied with the free limb of lever. A tension of $4 \mathrm{~g}$ and magnification of $10 \mathrm{X}$ was maintained.

Table No 6 : Activity of Polyherbal drugs on isolated perfused frog heart

\begin{tabular}{|c|c|c|c|c|c|c|}
\hline S.No.. & Drug & $\begin{array}{l}\text { Dose } \\
(\mathrm{mg} / \mathrm{ml})\end{array}$ & $\begin{array}{l}\text { Cardiac } \\
\text { Rate }\end{array}$ & $\begin{array}{l}\text { Cardiac } \\
\text { Rhythm }\end{array}$ & $\begin{array}{l}\text { Cardiac } \\
\text { Tone }\end{array}$ & $\begin{array}{l}\text { Cardiac } \\
\text { Contractility }\end{array}$ \\
\hline \multirow{5}{*}{$\begin{array}{l}1 . \\
2 . \\
3 .\end{array}$} & \multirow{5}{*}{$\begin{array}{l}\text { Shirishadi } \\
\text { Extract }\end{array}$} & 5 & 42 & \multirow[t]{5}{*}{ Regular } & \multirow[t]{5}{*}{ Increase } & \multirow[t]{5}{*}{ Stimulant } \\
\hline & & 10 & 46 & & & \\
\hline & & 20 & 50 & & & \\
\hline & & 10 & 52 & & & \\
\hline & & 20 & 54 & & & \\
\hline
\end{tabular}

Normal Heart Rate before administration of Drug= 54/min, Heart rate after Acetylcholine =22/min

Bronchodilator effect (Sheth et al., 1972)

Guinea pigs of either sex weighing 350 - $500 \mathrm{~g}$ were selected and randomly divided into four groups each containing four animals. The drugs were dissolved in distilled water and administered orally through intubation canula. The single dose treatments were given one and half an hour before the study. Group I was administered 0.5\% CMC (control), Group II: Mepyramine melate (10 mg/kg=0.1\% Soln.) (standard), Group III: Alcoholic extract of Shirishadi compound $(100 \mathrm{mg} / \mathrm{kg})$, Group IV: Alcoholic extract of Shirishadi compound $(200 \mathrm{mg} / \mathrm{kg})$. 
One and half hour later the animals were exposed to $0.2 \%$ histamine aerosol and time for pre convulsion state (PCD) was noted for each animal. The end point for PCD was determined from the time of aerosol exposure to the onset of dyspnoea leading to the appearance of convulsions. As soon as PCD commenced, the animals were removed from chamber and placed in fresh air to recover. This time for PCD was taken as day 0 value. After 15 days of wash out period, the animal of group III, IV,V \& VI were again given same schedule of drug and exposed to histamine aerosol and the time for PCD was noted. The $\%$ increase in time of PCD was calculated using the following formula.

Percentage increase in time of PCD $=1-\mathrm{T}_{1} / \mathrm{T}_{2} \mathrm{X} 100$

Where: $\mathrm{T} 1=$ time for PCD onset on day $0, \mathrm{~T} 2=$ time for PCD onset on day 15 .

Table No 7 : Effect of polyherbal formulations on histamine-aerosol in guinea pigs

\begin{tabular}{|l|l|l|l|l|}
\hline Treatment & Dose $(\mathbf{m g} / \mathbf{k g})$ & $\begin{array}{l}\text { Onset of convulsion } \\
\text { in sec. }\end{array}$ & $\begin{array}{l}\text { Protection } \\
(\%)\end{array}$ & $\begin{array}{l}\text { \% Increase in } \\
\text { preconvulsion time }\end{array}$ \\
\hline Control & $\begin{array}{l}\text { Saline, } \\
1.0 \mathrm{ml} / \mathrm{kg}\end{array}$ & $91.45 \pm 0.093$ & 0 & 0 \\
\hline Mepyramine & $10 \mathrm{mg} / \mathrm{Kg}$ & $1028.0 \pm 4.553$ & $90^{* * *}$ & $33.93 \pm 3.12$ \\
\hline $\begin{array}{l}\text { Shirishadi } \\
\text { Compound }\end{array}$ & 100 & $800 \pm 0.396$ & $80^{* *}$ & $27.85 \pm 3.96^{* * *}$ \\
\hline $\begin{array}{l}\text { Shirishadi } \\
\text { Compound }\end{array}$ & 200 & $860 \pm 0.674$ & $86^{* * *}$ & $36.13 \pm 3.68^{* * *}$ \\
\hline
\end{tabular}

$\mathrm{n}=6$ in each group; $* * P<0.01, * * * P<0.001$ vs. control; $(\chi 2$ test with Yate's correction).

\section{Assessment of Anti-histaminic activity of Polyherbal compounds on Isolated Guinea Pig ileum}

Overnight fasted guinea pigs of either sex weighing 400 - $600 \mathrm{~g}$ were sacrificed using cervical dislocation method. The lower most $10 \mathrm{~cm}$ of ileum was removed from the abdomen and placed in a shallow dish containing warm Tyrode solution. Ileum lumen was cleaned by passing through warm $0.9 \%$ saline and then segments about one inch in length, were made. The mesentric attachment and blood etc. were carefully cleaned and the tissues was mounted in a thermostatically controlled Dale's organ bath (temp. $37 \pm 0.5^{0} \mathrm{C}$ ) containing 20 $\mathrm{ml}$ Tyrode's solution under basal tension of $500 \mathrm{mg}$. The composition of solution in $\mathrm{mM}$ was $\mathrm{NaCl}, 137 ; \mathrm{CaCl} 2$, 1.8; KCl, 2.7; glucose, 5.55; NaHCO3, 11.9; $\mathrm{MgCl} 2$, 1; NaH2PO4, 0.4. The solution was continuously bubbled with air. The responses to drug were recorded on a Student physiograph (Bio Devices) using isotonic transducer, which exerted a basal tension equivalent to $500 \mathrm{mg}$ load on tissue. The issue was allowed to equilibrate for 30 min, during which, the bathing solution was changed at every $10 \mathrm{~min}$. Increasing concentration of histamine were added to the bath and the control cumulative concentration- response curve was constructed.

Table No 8 : Results obtained from guinea pig ileum preparation after treatment with Shirishadi Extract.

\begin{tabular}{|l|l|l|l|l|l|l|}
\hline S.No. & $\begin{array}{l}\text { Dose of } \\
\text { Histamine } \\
\mathbf{( 1 0} \mathbf{\mu g} / \mathbf{m l})\end{array}$ & $\begin{array}{l}\text { Log molar } \\
\text { concentrati } \\
\text { on } \\
\text { Histamine }\end{array}$ & $\begin{array}{l}\text { Control } \\
\text { maximum } \\
\text { response }\end{array}$ & $\begin{array}{l}\text { Standard \% } \\
\text { maximum } \\
\text { response }\end{array}$ & $\begin{array}{l}\text { Conc. of } \\
\text { Shirishadi } \\
\text { Extract } \\
\text { (mg/ml) } \\
+ \\
\mathbf{1 . 6 m l} \text { of } \\
\text { Histamine } \\
(\mathbf{1 0 \mu g} / \mathrm{ml})\end{array}$ & $\begin{array}{l}\text { \% Inhibition of } \\
\text { maximum } \\
\text { Histamine } \\
\text { contraction }\end{array}$ \\
\hline 1. & $0.1 \mathrm{ml}$ & 7.08 & $32.56 \pm 1.023$ & $12.55 \pm 1.560$ & $0.5 \mathrm{mg}$ & $20.98 \pm 2.28$ \\
2. & $0.2 \mathrm{ml}$ & 6.79 & $51.91 \pm 1.450$ & $23.10 \pm 2.065$ & $1.0 \mathrm{mg}$ & $31.56 \pm 2.01$ \\
3. & $0.4 \mathrm{ml}$ & 6.48 & $78.26 \pm 2.030$ & $35.23 \pm 1.020$ & $10 \mathrm{mg}$ & $43.05 \pm 1.31$ \\
4. & $0.8 \mathrm{ml}$ & 6.18 & $92.90 \pm 2.560$ & $42.65 \pm 1.67$ & $20 \mathrm{mg}$ & $65.78 \pm 1.20$ \\
5. & $1.6 \mathrm{ml}$ & 5.88 & $99.58 \pm 1.051$ & $51.32 \pm 1.25$ & $50 \mathrm{mg}$ & $83.78 \pm 1.43$ \\
& & & & & $80 \mathrm{mg}$ & $65.78 \pm 1.20$ \\
\hline
\end{tabular}

Values are expressed as mean \pm SEM $(n=6) .{ }^{*} \mathrm{p}<0.05$ when compared to control group, $* * p<0.05$ when compared to standard group. 


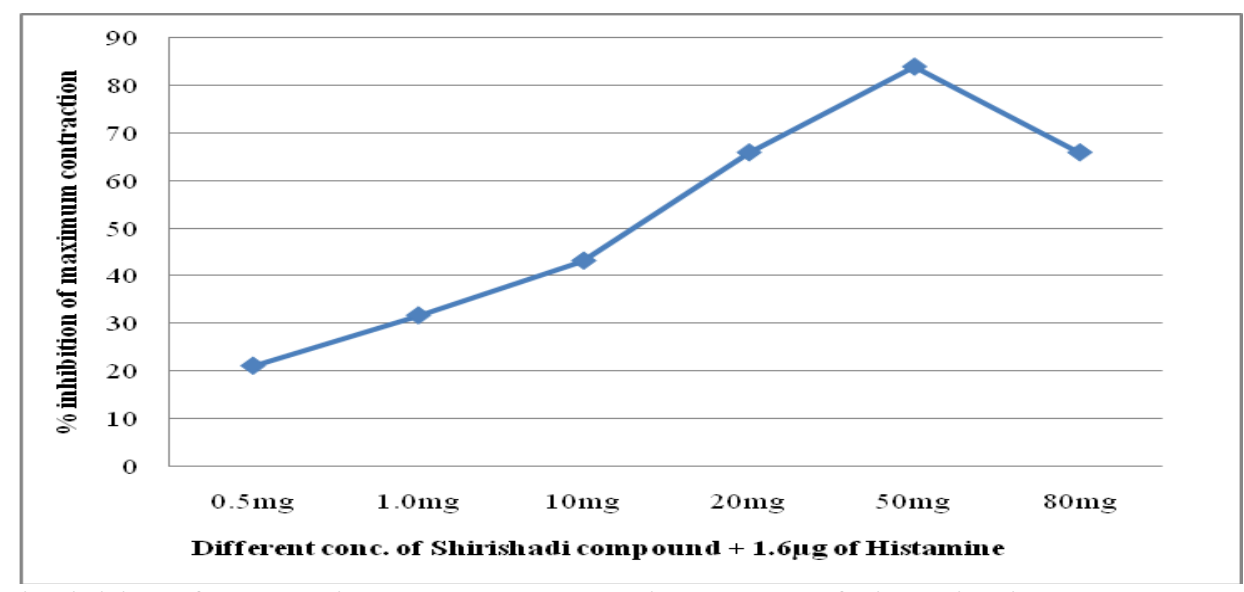

Fig. 19 : \% inhibition of contraction produced by maximum dose of histamine in the presence of different concentration of Shirishadi Compound.

\section{Studies on Compound 48/80 Induced Rat Mesentric Mast Cell Degranulation}

Rats were sacrificed by cervical dislocation and their abdomen was opened wide. Small intestine from jejunum to proximal $2 / 3$ of ileum along with the entire mesenteric attachment was removed into a beaker containing Ringer Lockes solution at $37^{0} \mathrm{C}$, with continuous oxygenation through a capillary tube. Piece of suitable size to include 2-3 arcades of mesenteric vessels were made and the mesentery was then cut out in one piece by gentle dissection. Five to eight good mesenteric pieces can be obtained per animal. The mesentery were collected in petri dish containing Ringer Locke solution and then subjected to the following treatment schedules. Petri dish no. 1 - Ringer Locke solution (Positive control),Petri dish no. 2 - $0.1 \mathrm{ml}$ of Ketotifen fumarate (10 $\mu \mathrm{g} / \mathrm{ml}$ ),Petri dish no. $3-0.1 \mathrm{ml}$ of test agent in Tween-80 (Shirishadi compound, $500 \mu \mathrm{g} / \mathrm{ml}$ ),Petri dish no. 4 $0.1 \mathrm{ml}$ of test agent in Tween-80 (Shirishadi compound, $1000 \mu \mathrm{g} / \mathrm{ml}$ )

Each petridish was incubated for $15 \mathrm{~min}$ at $37^{\circ} \mathrm{C}$. Later Compound $48 / 80(0.1 \mathrm{ml}, 10 \mu \mathrm{g} / \mathrm{ml})$ was added to each petri dish and again incubated for $10 \mathrm{~min}$. at $37^{\circ} \mathrm{C}$. After that, all pieces were transferred to $4 \%$ formaldehyde solution containing $0.1 \%$ toluidine blue and kept a side for 20 to $25 \mathrm{~min}$. After staining and fixation of mast cells, mesentery pieces were transferred through acetone and xylene two times and mounted on slides. All the pieces were examined under the high power of light microscope.

Table No 9 : Effect of Polyherbal compounds on Compound 48/80 induced rat mesentric mast cell degranulation

\begin{tabular}{|lcc|}
\hline Treatment groups & Concentration $(\boldsymbol{\mu g} / \mathbf{m l})$ & $\%$ inhibition of degranulation \\
Positive control & - & $9.83 \pm 1.58$ \\
Kitotifen & 10 & $80.67 \pm 3.30^{*}$ \\
Shirishadi compound & 500 & $60.87 \pm 1.19^{*}$ \\
Shirishadi compound & 1000 & $66.83 \pm 2.19^{*}$
\end{tabular}

Results are expressed in mean \pm SEM $(\mathrm{n}=6)$.

${ }^{*} \mathrm{p}<0.001$ as compared to Positive control group (One way ANOVA followed by Tukey's multiple range test).

\section{LUNG REMODELLING}

After giving medicine (Shirishadi) in the dose of 2.5ml-B.D. for 15 days in patients of moderate asthma with FVC $<1.50 \pm 0.45$, PEFR $<120 \pm 20$ and FEV1 $1.20 \pm 0.20$, we had taken Volume versus Time variation through graphical method.

The parameters which are used to evaluate the effect of medicine in term of mechanics are volume, pressure, airways resistance and compliance. To evaluate the effect of drug we had fitted a suitable MATLAB model using following models and assumptions:

- We estimates the following types of models and adds the following to the System Identification Tool GUI (Graphical User Interphase) in MATLAB with default names:

- $\quad$ IMP - Step response over a period of time .

- $\quad \mathrm{SPAD}$ - Frequency response over a range of frequencies .

- $\quad$ ARXQS - Fourth-order autoregressive (ARX) model . 


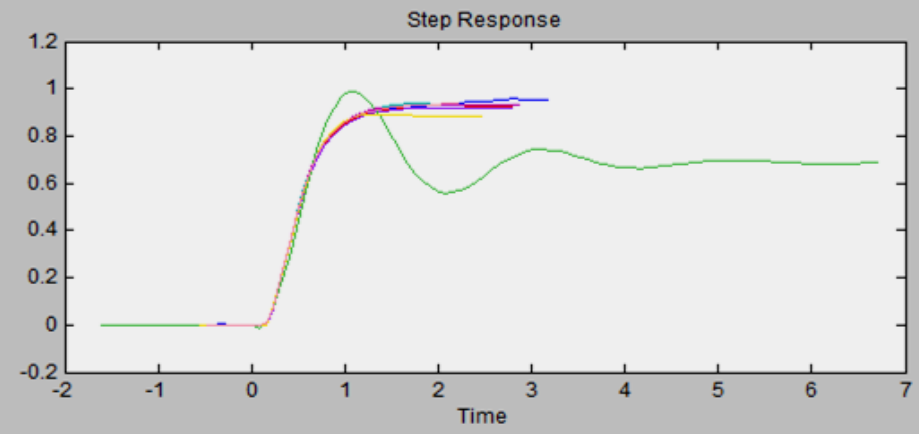

No transient response for SPA model.

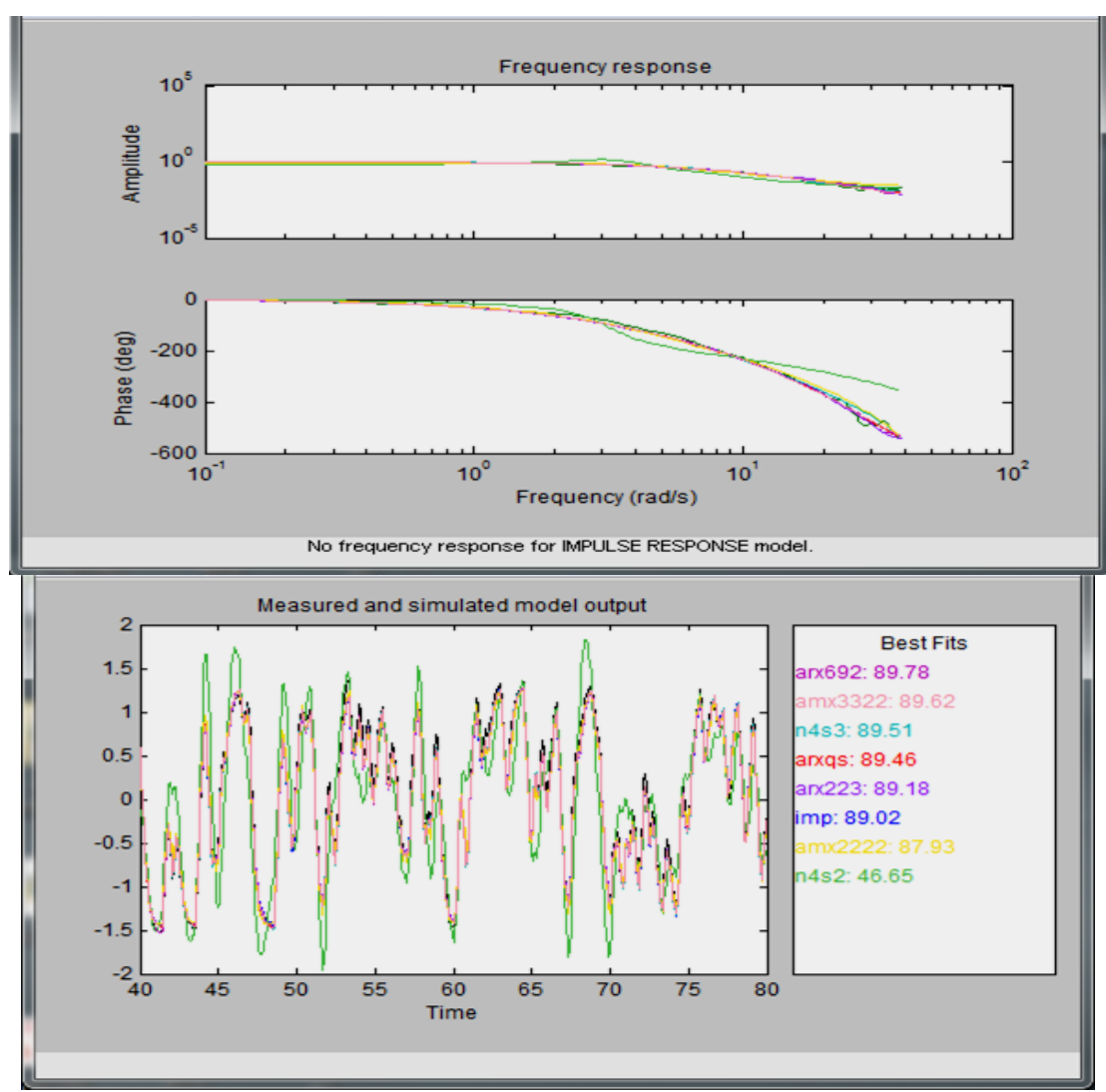

\section{Clinical Study}

An open, randomized and control clinical study on 60 (out of which patients drop-out due to various reasons) known patients of Bronchial Asthma showed the following improvement in pulmonary function test:

Table No. 10: Clinical Study of Shirishadi compound on PEFR (Peak Expiratory Flow Rate) in Bronchial Asthma

\begin{tabular}{|c|c|c|c|c|c|c|c|c|c|}
\hline \multirow[t]{2}{*}{ Groups } & \multicolumn{4}{|c|}{$\begin{array}{l}\text { PEFR } \\
\text { Mean } \pm \text { S.D. }\end{array}$} & \multicolumn{5}{|c|}{$\begin{array}{l}\text { Within the group comparison } \\
\text { paired t test }\end{array}$} \\
\hline & BT & AT & F1 & F2 & BT-AT & BT-F1 & AT-F1 & BT-F2 & AT-F2 \\
\hline Group I & $\begin{array}{l}120 \pm \\
38.0\end{array}$ & $\begin{array}{l}210 \pm \\
69.6\end{array}$ & $\begin{array}{l}207 \pm \\
65.6\end{array}$ & $\begin{array}{l}197 \pm \\
61.8\end{array}$ & $\begin{array}{l}90 \pm \\
58.4 \\
t=6.71 \\
p<0.001\end{array}$ & $\begin{array}{l}87.3 \pm \\
54.9 \\
t=6.92 \\
p<0.001\end{array}$ & $\begin{array}{l}77.6 \pm \\
49.7 \\
t=6.80 \\
p<0.001\end{array}$ & $\begin{array}{l}2.63 \pm \\
9.3 \\
t=1.22 \\
p>0.05\end{array}$ & $\begin{array}{l}12.3 \pm \\
13.3 \\
t=4.03 \\
p<0.001\end{array}$ \\
\hline Group II & $\begin{array}{l}138 \pm \\
72.2\end{array}$ & $\begin{array}{l}194 \pm \\
80.0\end{array}$ & $\begin{array}{l}141 \pm \\
60.7\end{array}$ & $\begin{array}{l}138 \pm \\
58.1\end{array}$ & $\begin{array}{l}55.6 \pm \\
29.6 \\
t=7.50 \\
p<0.001\end{array}$ & $\begin{array}{l}3.12 \pm \\
31.9 \\
t=0.39 \\
p>0.05\end{array}$ & $\begin{array}{l}52.51 \pm 32 . \\
76 \\
t=6.41 \\
p<0.001\end{array}$ & $\begin{array}{l}0.62 \pm \\
24.3 \\
t=0.10 \\
p>0.05\end{array}$ & $\begin{array}{l}56.2 \pm \\
32.0 \\
t=7.02 \\
p<0.001\end{array}$ \\
\hline Group III & $\begin{array}{l}141.0 \pm \\
44.3\end{array}$ & $\begin{array}{l}134 \pm \\
48.9\end{array}$ & $\begin{array}{l}134 \pm \\
48.8\end{array}$ & $\begin{array}{l}131 \pm \\
43.8\end{array}$ & $\begin{array}{l}6.5 \pm 10.5 \\
t=1.94 \\
p>0.05\end{array}$ & $\begin{array}{l}7.0 \pm \\
9.48 \\
t=2.33\end{array}$ & $\begin{array}{l}0.50 \pm \\
6.85 \\
t=0.23\end{array}$ & $\begin{array}{l}10.0 \pm \\
11.54 \\
t=2.73\end{array}$ & $\begin{array}{l}3.50 \pm \\
14.5 \\
t=0.761\end{array}$ \\
\hline
\end{tabular}


In-Vitro and In-Vivo Assessment of Anti-Asthmatic Activity of Polyherbal Ayurvedic Drug

\begin{tabular}{|c|c|c|c|c|c|c|c|c|}
\hline & & & & & $\mathrm{p}<0.05$ & $\mathrm{p}>0.05$ & $\mathrm{p}<0.05$ & $\mathrm{p}>0.05$ \\
\hline $\begin{array}{l}\text { Between the } \\
\text { Group } \\
\text { comparison } \\
\text { One Way } \\
\text { ANOVA }\end{array}$ & $\begin{array}{l}\mathrm{F}=0.44 \\
\mathrm{P}>0.05\end{array}$ & $\begin{array}{l}\mathrm{F}=2.1 \\
2 \\
\mathrm{P}=>0 . \\
05\end{array}$ & $\begin{array}{l}\mathrm{F}=3.50 \\
\mathrm{P}=<0.05\end{array}$ & $\begin{array}{l}\mathrm{F}=3.15 \\
\mathrm{P}<0.05\end{array}$ & & & & \\
\hline $\begin{array}{l}\text { POST HOC } \\
\text { TEST } \\
\text { SIGNIFICANT } \\
\text { PAIRS }(\mathbf{P}<.05)\end{array}$ & None & None & $\begin{array}{l}(1,3) \\
(2,3)\end{array}$ & $\begin{array}{l}(1,3) \\
(2,3)\end{array}$ & & & & \\
\hline
\end{tabular}

Table No. 11: Clinical Study of Shirishadi compound on FVC (Forced Vital Capacity) in Bronchial Asthma

\begin{tabular}{|c|c|c|c|c|c|c|c|c|c|}
\hline \multirow[t]{2}{*}{ Groups } & \multicolumn{4}{|c|}{$\begin{array}{l}\text { FVC } \\
\text { Mean } \pm \text { S.D. }\end{array}$} & \multicolumn{5}{|c|}{ Within the group comparison paired $t$ test } \\
\hline & BT & AT & F1 & F2 & BT-AT & BT-F1 & AT-F1 & BT-F2 & AT-F2 \\
\hline Group I & $\begin{array}{l}1.55 \pm 0 \\
.53\end{array}$ & $\begin{array}{l}2.16 \pm 0.5 \\
5\end{array}$ & $\begin{array}{l}2.17 \pm \\
0.49\end{array}$ & $\begin{array}{l}2.18 \pm \\
0.50\end{array}$ & $\begin{array}{l}0.60 \pm \\
0.44 \\
t=5.90 \\
p<0.001 \\
\end{array}$ & $\begin{array}{l}10.3 \pm \\
42.1 \\
t=1.06 \\
p>0.05\end{array}$ & $\begin{array}{l}9.70 \pm \\
42.2 \\
t=1.00 \\
p>0.05\end{array}$ & $\begin{array}{l}0.62 \pm \\
0.55 \\
t=4.90 \\
p<0.001 \\
\end{array}$ & $\begin{array}{l}.0016 \pm \\
0.27 \\
t=0.25 \\
p>0.05\end{array}$ \\
\hline Group II & $\begin{array}{l}1.18 \pm 0 \\
.75\end{array}$ & $\begin{array}{l}2.10 \pm 0.8 \\
0\end{array}$ & $\begin{array}{l}1.49 \pm \\
0.71\end{array}$ & $\begin{array}{l}1.54 \pm \\
0.73\end{array}$ & $\begin{array}{l}0.92 \pm \\
0.32 \\
t=11.4 \\
p<0.001\end{array}$ & $\begin{array}{l}0.31 \pm \\
0.47 \\
t=2.50 \\
p<0.05\end{array}$ & $\begin{array}{l}0.61 \pm \\
0.43 \\
t=5.71 \\
p<0.001\end{array}$ & $\begin{array}{l}0.36 \pm \\
0.42 \\
t=3.4 \\
p<0.001\end{array}$ & $\begin{array}{l}0.56 \pm \\
0.35 \\
t=6.26 \\
p<0.00 \\
1\end{array}$ \\
\hline Group III & $\begin{array}{l}1.07 \pm 0 \\
.53\end{array}$ & $\begin{array}{l}1.03 \pm 0.4 \\
8\end{array}$ & $\begin{array}{l}1.04 \pm \\
0.43\end{array}$ & $\begin{array}{l}1.02 \pm \\
0.45\end{array}$ & $\begin{array}{l}0.003 \pm \\
0.13 \\
t=0.914 \\
p>0.05\end{array}$ & $\begin{array}{l}2.70 \pm \\
0.16 \\
t=0.50 \\
p>0.05\end{array}$ & $\begin{array}{l}0.001 \pm \\
7.47 \\
t=-0.46 \\
p>0.05\end{array}$ & $\begin{array}{l}0.004 \pm \\
0.17 \\
t=0.79 \\
p>0.05\end{array}$ & $\begin{array}{l}0.0006 \\
\pm 9.7 \\
t=0.194 \\
p>0.05\end{array}$ \\
\hline $\begin{array}{l}\text { Between the } \\
\text { Group } \\
\text { comparison } \\
\text { One Way } \\
\text { ANOVA }\end{array}$ & $\begin{array}{l}\mathrm{F}=1.0 \\
0 \\
\mathrm{P}>0.0 \\
5\end{array}$ & $\begin{array}{l}F=6.63 \\
P<0.001\end{array}$ & $\begin{array}{l}\mathrm{F}=0.88 \\
\mathrm{P}=<0.00 \\
1\end{array}$ & $\begin{array}{l}\mathrm{F}=8.01 \\
\mathrm{P}<0.00 \\
1\end{array}$ & & & & & \\
\hline $\begin{array}{l}\text { POST HOC } \\
\text { TEST } \\
\text { SIGNIFICA } \\
\text { NT PAIRS } \\
(\mathbf{P}<.05) \\
\end{array}$ & None & $\begin{array}{l}(1,3) \\
(2,3)\end{array}$ & $\begin{array}{l}(1,3) \\
(2,3)\end{array}$ & $\begin{array}{l}(1,3) \\
(2,3)\end{array}$ & & & & & \\
\hline
\end{tabular}

Table No. 12 : Clinical Study of Shirishadi compound on FEV1 (Forced Expiratory Volume)in Bronchial Asthma

\begin{tabular}{|c|c|c|c|c|c|c|c|c|c|}
\hline \multirow[t]{2}{*}{ Groups } & \multicolumn{4}{|c|}{$\begin{array}{l}\text { FEV1 } \\
\text { Mean + S.D. }\end{array}$} & \multicolumn{5}{|c|}{ Within the group comparison paired t test } \\
\hline & BT & AT & F1 & F2 & BT-AT & BT-F1 & AT-F1 & BT-F2 & AT-F2 \\
\hline Group I & $\begin{array}{l}1.45 \pm \\
0.60\end{array}$ & $\begin{array}{l}2.09 \pm \\
0.61\end{array}$ & $\begin{array}{l}2.06 \pm \\
0.63\end{array}$ & $\begin{array}{l}1.9 \pm \\
0.60\end{array}$ & $\begin{array}{l}0.61 \pm \\
0.48 \\
t=5.50 \\
p<0.00 \\
1\end{array}$ & \begin{tabular}{|l|}
$0.58 \pm$ \\
0.50 \\
$t=5.00$ \\
$p<0.001$
\end{tabular} & $\begin{array}{l}0.003 \pm \\
0.12 \\
t=1.17 \\
p>0.05\end{array}$ & $\begin{array}{l}0.50 \pm \\
0.50 \\
t=4.38 \\
p<0.001\end{array}$ & $\begin{array}{l}.10 \pm \\
0.12 \\
t=3.79 \\
p<0.001\end{array}$ \\
\hline Group II & $\begin{array}{l}1.13 \pm \\
0.42\end{array}$ & $\begin{array}{l}1.60 \pm \\
0.57\end{array}$ & $\begin{array}{l}1.36 \pm \\
0.49\end{array}$ & $\begin{array}{l}1.40 \pm \\
0.47\end{array}$ & $\begin{array}{l}0.46 \pm \\
0.31 \\
t=5.9 \\
p<0.00 \\
1\end{array}$ & \begin{tabular}{|l|}
$0.22 \pm$ \\
0.31 \\
$t=2.8$ \\
$p<0.01$
\end{tabular} & $\begin{array}{l}0.24 \pm \\
0.30 \\
t=3.13 \\
p<0.001\end{array}$ & $\begin{array}{l}0.26 \pm \\
0.21 \\
t=3.5 \\
p<0.001\end{array}$ & $\begin{array}{l}0.20 \pm \\
0.26 \\
t=3.07 \\
p<0.001\end{array}$ \\
\hline Group III & $\begin{array}{l}1.14 \pm \\
0.51\end{array}$ & $\begin{array}{l}1.10 \pm \\
0.49\end{array}$ & $\begin{array}{l}1.09 \pm \\
0.54\end{array}$ & $\begin{array}{l}1.16 \pm \\
0.42\end{array}$ & $\begin{array}{l}0.003 \pm \\
0.009 \\
t=1.2 \\
p>0.05\end{array}$ & $\begin{array}{l}0.004 \pm \\
0.22 \\
t=0.62 \\
p>0.05\end{array}$ & $\begin{array}{l}0.002 \pm \\
0.14 \\
t=-0.62 \\
p>0.05\end{array}$ & $\begin{array}{l}0.0009 \pm \\
0.21 \\
t=0.13 \\
p>0.05\end{array}$ & $\begin{array}{l}0.006 \pm \\
0.14 \\
t=1.36 \\
p>0.05\end{array}$ \\
\hline $\begin{array}{l}\text { Between the } \\
\text { Group } \\
\text { comparison } \\
\text { One Way } \\
\text { ANOVA }\end{array}$ & $\begin{array}{l}F=2.39 \\
P>0.05\end{array}$ & $\begin{array}{l}\mathrm{F}=5.31 \\
\mathrm{P}<0.001\end{array}$ & $\begin{array}{l}\mathrm{F}=6.50 \\
\mathrm{P}=<0.001\end{array}$ & $\begin{array}{l}F=5.49 \\
P<0.00 \\
1\end{array}$ & & & & & \\
\hline $\begin{array}{l}\text { POST HOC } \\
\text { TEST } \\
\text { SIGNIFICA } \\
\text { NT PAIRS } \\
(P<.05)\end{array}$ & None & $\begin{array}{l}(1,3) \\
(2,3)\end{array}$ & $\begin{array}{l}(1,3) \\
(2,3)\end{array}$ & $\begin{array}{l}(1,3) \\
(2,3)\end{array}$ & & & & & \\
\hline
\end{tabular}




\section{Discussion}

Pharmacodynamic Screening of Drug Screening the activity of drug on antiasthmatic parameters such as antihistaminic, anti-cholinergic, bronchodilator,mast cell stabilizing activity, anti PAF activity,anti-inflammatory and analgesic activity and immunomodulator effect to assess probable mode of action of drug shows that the drug possess anti-histaminic property. The non-competitive and preventive type of antagonism with dose dependent response was obtained. There was right shift of the dose response curve in the presence of drug showing the efficacy of drug. Though the anti-histaminic activity is present in the drugs but the dose at which the response obtained is much more than those use for the therapeutic purpose. Brochodilation produced against histamine induced bronchoconstriction confirm the anti-histaminic activity of drugs. No anticholinergic activity was encountered in polyherbal drug. Evaluating anti-cholinergic activity on isolated perfused heart showed that drug was unable to prevent the acetylcholine induced cardiac arrest though the time-span of cardiac arrest was significantly reduced and the heart rate regains its rythmicity and contractility in presence of polyherbal drug but the cardiac arrest was not totally prevented.

The Shirishadi extract produces $30 \pm 0.23 \%$ inhibition in maximum contraction produce by Acetylcholine which is much less than that produce by standard drug $(99.9 \%)$, moreover the dose of extract that produce the visible effect is much higher than that use for therapeutic purpose suggesting that antiasthmatic effect of drug is not due to Acetylcholine antagonism activity. Neither Acetylcholine efficacy nor its potency decreases significantly with increasing dose of drug as shown by left shifting of graph.

Egg induced anaphylactic response was significantly prohibited by the polyherbal drug and there is $0.00 \%$ mortality in group treated with polyherbal drug against $70 \%$ mortality in control group (untreated group). The findings reveal protection against egg albumin induced anaphylactic shock characterized by decrease in intensity and delay in the development of symptoms of dyspnoea, asphyxia and collapse. In line with this notion, anti-anaphylactic effect of Shirishadi may be due to inhibition of phenomenon of sensitization or nonavailability of antibodies on the mast cell surface. The \% inhibition of MCD (mast cell degranulation) was found to be $60.87 \%$ and $66.83 \%$ in 500 , and $1000 \mu \mathrm{g} / \mathrm{ml}$ of Shirishadi compound. Prior exposure to Polyherbal compounds produced significant $(\mathrm{p}<0.001)$ reduction in the Compound $48 / 80$-induced mast cell degranulation. Seven days treatment produces no significant change in weight of adrenal gland and spleen, proving that there are no evidences that the drug in any way stimulates the adrenal gland. Evaluation of effect of hydroethanolic extract of Shirishadi on Cyclophosphamide induced immunosuppression indicated good protection by increasing all the hematological parameters. WBC count, RBC count, and \% hemoglobin values observed were better than untreated control groups. Administration of Cyclophosphamide produced a significant decrease in the Total Leukocyte Count from $6.2 \pm 0.081$ to $2.98 \pm 0.214$, RBC count from $5.02 \pm 0.116$ to $3.02 \pm 0.152$, and \% hemoglobin from $15.49 \pm 0.081$ to $9.32 \pm 0.153(\mathrm{P}<0.01)$. Shirishadi treated group showed WBC count $=5.92 \pm$ $0.52, \mathrm{RBC}$ count $=5.64 \pm 1.53, \mathrm{Hbgm} \%=14.48 \pm 0.93$ and Neutrophil adhesion $26.07 \pm 1.043(\mathrm{p}<0.001)$.

In the carrageenan-induced rat paw edema test for acute inflammation, the extract of Shirishadi compound in doses of 50mg, $200 \mathrm{mg}$ and $500 \mathrm{mg} / \mathrm{kg}$ body weight showed $77 \%$ and $79 \%$ and $81 \%$ inhibition of edema, at the end of $4 \mathrm{~h}$, which is comparable to that of standard (endomethacin) i.e. $92 \%$. In the acetic acid induced writhing test the extract of Shirishadi compound (200 and $500 \mathrm{mg} / \mathrm{kg}$ body weight) showed a significant $(p<0.001)$ reduction in the number of writhes with $65.6 \%$ and $70.9 \%$ of inhibition respectively . In radiant heat tail-flick test Shirishadi crude extract produced $58.1 \%(p<0.001)$ and $61.10 \%(p<0.001)$ elongation of tail flicking time 30 minutes after oral doses of 200 and $500 \mathrm{mg} / \mathrm{kg}$ body weight respectively . After 60 minutes the extract showed $56.3 \%(p<0.001)$ and $59.00 \%(p<0.001)$ elongation of tail flicking time.

Study of change in Lung Mechanics through Parametric model: Graphical variation obtained after administration of drug Shirishadi was changed using MATLEB model to evaluate the action of drug on various parameters. The graphical variations strongly confirm that drug decrease the airway resistance, increase the lung volume, increases the lung compliance.

Clinical study: Evaluation of Pulmonary function test showed significant improvement in FVC, PEFR and FEV1 in group treated with polyherbal compound. The most striking fact observed is that the changes were remained constant throughout follow-up, showing no reverse bronchoconstriction. Shirishadi compound was found to be more effective in allergic asthma. Treatment with Polyherbal compound decreases the frequency of attack as well as severity of attack on exposure to allergens.

\section{Conclusion}

It can be concluded that Polyherbal compounds Shirishadi has potent antiasthmatic activity. It can be further concluded that these Polyherbal compound can be used as 'Therapeutic Agent' in the management of acute attack of Asthma as well as chronic persistent Asthma. The trial gives a direction for searching new route of herbal drug administration. 


\section{References}

[1]. Achinto Saha and Muniruddin Ahmed; The Analgesic and Anti-inflammatory activities of the extract of Albizzia lebbeck in animal model; Pak. J. Pharm. Sci., Vol.22, No.1, January 2009, pp.74-77.

[2]. Babu N P et al; Anti-inflammatory activity of Albizzia lebbeck Benth., an ethnomedicinal plant, in acute and chronic animal models of inflammation. J Ethnopharmacol. 2009 Sep 7;125(2):356-60. Epub 2009 Mar 9.

[3]. Mohammad Yaheya Mohammad Ismail. Antiasthmatic Herbal Drugs - A Review ; International Journal of Pharmacy and Pharmaceutical Sciences. Vol 2, Issue 3, 2010.

[4]. Pichairajan Venkatesh et al ; Anti-allergic activity of standardized extract of Albizzia lebbeck with reference to catechin as a phytomarker; Immunopharmacol Immunotoxicol 32(2):272-6 (2010).

[5]. Tripathi R .M, Sen P. C, Das P K . Studies on the mechanism of action of Albizzia lebbeck, an Indian indigenous drug used in the treatment of atopic allergy; Journal of Ethnopharmacology. Vol 1, Issue 4, December 1979, pp 385-396.

[6]. Jain, et al. Effect of S. xanthocarpum on pulmonary function. Ind J Physiol Pharmacol.1977, 22(1):31-32.

[7]. Jain J.P. A clinical trial of Kantakari (Solanum xanthocarpum) in case of Kasa roga. J.Res Ayur Siddha. 1980,1:447-460.

[8]. Shraddha Anwikar \& Milind Bhitre. Study of the synergistic anti-inflammatory activity of Solanum xanthocarpum Schrad and Wendl and Cassia fistula Linn. IJAR. 2010, 1: 3,pp : 167-171.

[9]. Srivastava S, Gupta PP, Prasad R, Dixit Kspalit G, Ali B, Misra G, Saxena RC, Evaluation of Antiallergic activity (type I hypersensitivity) of Inula racemosa in rats. Indian J physiol Pharmacol. 1999 Apr; 43(2): 235- 41.

[10]. D'Amour FE and Smith DL. A method for determining loss of pain sensation. J. Pharmacol. Exp.Ther.1941, 72: 74-79.

[11]. Govindan S, Viswanathan S, Vijayasekaran V, Alagappa R.Phytotherapy Research journal.2004, 18(10):805-809.

[12]. Gupta M P, Dutt S, J.Indian.Chem.Soc. 1938; 15: 95-100.

[13]. Gupta SS. Development of antihistamine and antiallergic activity after prolonged administration of a plant saponin from Clerodendron serratum. J Pharm Pharmac 1968;20:801-2.

[14]. Gupta SS. Indigenous drugs in experimental bronchial asthma. Aspect Aller Appl lmmunol 1971;5:31-42.

[15]. Linden A, Lofdahl C.G, Ullman A. and Skoogh B.E. Non-adrenergic noncholinergic responses stabilize smooth muscle tone with and without parasympathetic activation in guinea-pig isolated airways. Eur Respir J.1993, 6: 425-433.

[16]. R.M. Tripathi, P.C. Sen, P.K. Das, "Further studies on the mechanism of the anti-anaphylactic action of Albizzia lebbeck, an Indian indigenous drug", Journal of Ethnopharmacology;Volume-1; Issue-4; Page. No- 397-406;1979.

[17]. Saha A, Masud MA, Bachar SC, Kundu JK, Datta BK,Nahar L and Sarker SD (2007). The Analgesic and Anti-Inflammatory Activities of the Extracts of Phyllanthus reticulatus in Mice Model. Pharm Biol.,45(5): 355-359.

[18]. Tripathi RM, Das PK. Studies on anti-asthmatic and anti-anaphylactic activity of Albizzia lebbeck. Indian J. Pharmacol.1977. 9, 189194.

[19]. Vinegar R, Schreiber W and Hugo R. Biphasic development of carrageenin edema in rats. J. Pharmacol. Exp. Ther.1969,166: 96-103.

[20]. Winter CA, Risley EA and Nuss GW. carrageenin induced edema in hind paw of the rat as an assay for anti-inflammatory drugs. Proc. Soc. Exp. Biol. Med.1962,111: 544-547. 